\title{
Double Boundary and Cosmopolitan Experience in Europe
}

\section{Birindelli, Pierluca}

Palgrave Macmillan

2017-11

Birindelli , P 2017 , Double Boundary and Cosmopolitan Experience in Europe . in M Caselli \& G Gilardoni (eds) , Globalization, Supranational Dynamics and Local Experiences . Europe in a Global Context , Palgrave Macmillan , Cham , pp. 127-148 . https://doi.org/10.1007/978-3-319-64075-4_6

http://hdl.handle.net/10138/311084

https://doi.org/10.1007/978-3-319-64075-4_6

acceptedVersion

Downloaded from Helda, University of Helsinki institutional repository.

This is an electronic reprint of the original article.

This reprint may differ from the original in pagination and typographic detail.

Please cite the original version. 


\section{Double Boundary and Cosmopolitan Experience in Europe}

\section{Pierluca Birindelli}

\section{Abstract}

This contribution aims to open up the debate about national,

European and cosmopolitan identity through an interpretation of Simmel's double boundary dialectic: human beings are boundaries and only those who stand outside their boundaries can see them as such. One difficulty with defining oneself as European stems from what could be called the "double Other" (intra- and extra-European) diachronic recognition process. Exploring the possible/impossible cosmopolitan meta-synthesis can identify certain traits of the cosmopolitan experience in Europe.

Keywords: Boundary, Simmel, Europe, Cosmopolitan Culture, Trans-cultural, Trans-social. 


\section{Cultural Paradigms and the Double Boundary Dialectic}

Over the past 15 years the interdisciplinary field of study of "cosmopolitanism" has grown enormously: "There has appeared a plethora of writings on cosmopolitan thought and practice, testifying to cosmopolitanism's centrality across the social sciences and humanities" (Inglis 2014: 99). A plurality of paradigms has always occupied the field of social science, and at times one paradigm has prevailed partially over others. When the heuristic potential of a paradigm seemed to supersede others, it inaugurated a "turn", whether linguistic, cultural, narrative, and so on. Can the cosmopolitan approach be considered a leading paradigm? Are we facing another turn? Alternatively, is it time for an end to all "turns"?

These reflections concentrate on: considering cosmopolitanism as a "cultural paradigm"; thinking of the cosmopolitan approach as one vantage point in interpreting a culturally globalized world, thus adopting a methodologically 
and theoretically pluralistic approach; employing Georg Simmel's conceptualizations of "double boundary" to construct a possible viewpoint on cosmopolitanism in Europe; and using the "blasé" personality to point out a key attitude of the imagined cosmopolitan person.

If the adoption of a cosmopolitan approach stems from structural and cultural global changes, we can think of it not just as a heuristic concept but also as a cultural construct. Hence, cosmopolitanism must be understood in the same way we interpret any cultural construct, by theorizing the connection between the concept and the society(s). Cosmopolitanism would then become part of a larger, historically grounded interpretive system that not merely reflects social reality but grows with it. We can consider a scientific paradigm a purely epistemological construct, whereas a cultural paradigm is both an epistemological and an ontological construct. In defining a “cultural paradigm”, Arditi (1994) makes reference to Kuhn's 
conception of a scientific one: a heuristic device through which we can conceive the mechanisms of knowing and construct a model of the structure of knowledge. However, neither mechanisms nor model are supposed to impinge on the constitution of the social reality. A cultural paradigm, by contrast, inevitably affects the reality it comes to interpret: "What might start as an epistemological construct slowly becomes an element in the construction of social reality itself" (Arditi 1994: 604).

When cosmopolitanism is considered as a cultural phenomenon, sociologists' conceptualizations converge on an orientation of openness to foreign "others" and cultures. Some scholars consider the European Union (EU) (Beck and Grande 2007; Rifkin 2004) a leading example of a transnational institutional process that might foster a cosmopolitan spirit, while also being an economic, social and political process that can fruitfully be interpreted through the cosmopolitan approach. 
What will happen if Europeanization decreases in intensity? Should we then drop cosmopolitanism and go back to methodological nationalism in social research? Wouldn't it be more useful to contemplate a pluralism of paradigms?

Following Levine (1989), who sees Simmel as a source of sociological metatheory, we can consider different objections to methodological and theoretical pluralism. The monist objection can be roughly summarized as one contending position being valid and all the rest wrong, misleading or unimportant. A more sophisticated explanation is that, alternative approaches are historically valid but currently outmoded, necessary but transient stages in the evolution of current true belief, or partially valid positions that need to be incorporated in a more embracing theoretical synthesis. In my view, the cosmopolitan approach can be considered a sophisticated monist theoretical analysis of cultural globalization. The heart of methodological and theoretical pluralism is instead the belief that two or more 
divergent positions may be entirely acceptable. Simmel created the first major body of argumentation to support methodological (and theoretical) pluralism in the social sciences and is a key resource for sociological metatheory and a valid representative of methodological and theoretical pluralism (Levine 1989).

Simmel tells us that the prosecution of historical studies necessarily involves a plurality of different principles, which not only organize the historical materials in different ways but even prescribe different criteria of truth: "The kind of science humanity has at any given moment depends on the kind of humanity it is at that moment." (Simmel 1910/1959: 290) This passage seems to support a monist cosmopolitan approach. However, according to Frank (1987), Simmel places Schopenhauer (aimless will, pessimist, dogmatic denial of the worth of life) and Nietzsche (will to power, optimist, dogmatic affirmation of the value of life) in opposition. The most important aspect of this opposition is precisely that it does not 
admit reconciliation. The essence of Simmel's metatheory consists in his refusal of a definitive synthesis.

There can be no unification based on objective content, but only one achieved by a subject who can regard both positions. By sensing the reverberations of spiritual existence in the distance opened up by these opposites, the soul grows, despite, indeed, because of, the fact that it does not decide in favor of one of the parties. It finally embraces both the desperation and the jubilation of life as the poles of its own expansion, its own power, its own plenitude of forms. And it enjoys that embrace. (Simmel 1907/1986: 181)

For Simmel, the best we could do, both as reflexive actors living in a cosmopolitan world and as sociologists investigating such reflexive actors, is to step over different forms of boundaries. Simmel's double boundary dialectic (Weinstein and Weinstein 1989) can shed sociological light on theoretical pluralism and the key attitudes of the cosmopolitan person. The being who 
investigates his own being discovers irresolution, incompletion and paradox. The "formal structure of our existence", which is manifested "in countless ways in the diverse provinces, activities, and destinies of human life", is to stand "at every moment between two boundaries." No aspect of our existence can be defined unilaterally: "By virtue of the fact that we have boundaries everywhere and always, so accordingly we are boundaries" (Simmel 1918/1971: 353). The very essence of our existence is to be boundaries, but that does not mean that we are determinate or fixed within rigid limits; the actor is a mediative human being.

A cosmopolitan person who constructs bridges instead of walls through the substitution of the "either-or" with the "bothand" logic (Beck 2006) can be rightly imagined as a "mediative" human being. The question is what kinds of boundaries the citizen of our globalized world truly crosses and therefore what kinds of social groups and cultures he mediates. 
If boundaries cannot be evaded once and for all (the final synthesis or reconciliation), "every single determinate boundary can be stepped over", creating a new one. Above all, we might say that boundaries are made by those who cross them: "For only whoever stands outside his boundary in some sense knows that he stands within it" (Simmel 1918/1971: 355).

In Simmel's conception, the acknowledgement of a boundary opens the way to its transcendence. It is the human reflexive ability to transcend mental limits while remaining within them: any phase of human existence can only be known from a position that is outside it and yet remains within it. Simmel considers society to be one of those encompassing boundaries that human beings cannot escape, yet social actors need to distance (or even to isolate) themselves from society to participate in it as fully aware and reflexive actors. Society, therefore, lies on the boundary between nature and convention: 
We neither belong to it as members of an organism nor do we contrive it out of our isolated individualities. Instead, we co-constitute society as a boundary that we continually transcend as we remain within its confines. We cannot dispense with it, but we do dispense with it. (Weinstein and Weinstein 1989: 52)

Simmel's double boundary dialectics offers a two-sided conceptualization that works for both the layman and the scholar - although the reflexive cosmopolitan actor pointed out by many scholars at times seems a scholar.

\section{Boundaries' Recognition: Social and Cultural}

Having emphasized how in Simmel's view the human condition is defined by boundaries, I would like to imagine biographical experiences of the cosmopolitan agent that could promote an awareness of border crossing. As noted earlier, sociologists converge on an orientation of openness to foreign "others" and cultures. This minimum definitional agreement is inspired by 
Hannerz's seminal study of cosmopolitanism as “an orientation, a willingness to engage with the Other $[\ldots]$ an intellectual and aesthetic stance of openness toward divergent cultural experiences" as well as "the aspect of a state of readiness, a personal ability to make one's way into other cultures $[\ldots]$ a built-up skill in manoeuvring more or less expertly with a particular system of meanings and meaningful forms" (Hannerz 1990: 237-251).

Beyond consumption practices or exposure to the media, people who travel and experience otherness through transnational mobility are crucial subjects of cultural globalization and cosmopolitan studies. The social scientist necessarily faces a bifurcation toward two diverging fields of inquiry: people who choose to move and people who are forced to move. The core of my reflections is voluntary mobility or, in other words, the mobilities of privileged groups who hold a key role "both as a material and economic force and as a referential 
framework for how people in general may envision certain forms of travelling as part of the 'good life"' (Jansson 2016: 423).

The experience of travel can be considered a topos of the cosmopolitan person's habitus. We can imagine a cosmopolitan spirit fostered by the media, or an "at home" cosmopolitanism that does not involve geographical mobility, such as Lamont and Aksartova's (2002) "ordinary cosmopolitanism": the strategies used by ordinary people to bridge boundaries with people who are different from them. Still, it is worth exploring boundary crossing within the field of travel, the experience of crossing par excellence.

The cosmopolitan traveler, wrested from his ordinary surroundings, is forced into direct experience, and such direct experience makes him aware of who is having the experience. It provokes the discovery of identity traits that could not be visible in a familiar world: "Travel is the paradigmatic experience, the 
model of a direct and genuine experience, which transforms the person having it" (Leed 1991: 5).

Let us imagine different kinds of boundaries that the cosmopolitan person can cross while abroad, and therefore become aware of. I would like to use my personal experience as an example, which is part of an autoethnography included in my current research project: "The Cultural Experience of International Students: Narratives from North and South Europe" (Birindelli 2017).

The easiest boundary to point out is geographical: the physical crossing of borders while travelling. I recently moved from Florence, Italy to Helsinki, Finland, travelling by air. Many indicators told me that I was able to cross a geographical boundary. Although travelling by land would be a more vivid experience, I recognized the passing of the Alps. That meant I was outside the Italian Peninsula and heading north. Once I arrived in Helsinki, the colder climate, the morphology of the 
territory and the cityscape told me I was elsewhere in Northern Europe.

The political boundary was harder to recognize. I showed my identity card at the airport in Florence and that was it. As a citizen of the EU, I did not have an institution telling me that I was crossing a geopolitical boundary once I arrived at the destination. The passage became evident when I had to go to the police and register with the local authority as a resident of Helsinki: they gave me an ID number and the police officer, smiling, said "Welcome to the Kingdom of Finland!"

I was, of course, able to recognize the crossing of some boundaries in everyday life: the architecture and general layout of the city; public transport; shops, and so on. I realized I was slowly becoming more a part of "them", but who was measuring the distance from ego and alter? And according to which criteria? Can learning to recognize a product in a supermarket be considered a significant cultural passage? 
As a consumer, I realized the differences in certain products but mainly in price: I could find more or less the same basic items as in Italy, only more expensive. For the first time in my life I could taste wine from Chile, Argentina, South African wines that I would never be able to find in Italy. I started to eat salmon and reindeer. Although as an Italian this was a strong dietary passage, can I consider eating reindeer filet as the crossing of a cultural boundary? Does food really mean that much?

I knew I was not crossing any linguistic boundary. In Finland you get along very well speaking English in most if not all life spheres.

As a cultural sociologist, the biggest doubt is if I ever crossed a social and cultural boundary. I realized the presence of different lifestyles (Finns, for instance, love karaoke), attitudes (Finns are reserved and straightforward at the same time, which is the opposite of Italians) and modes of behavior (I've never 
seen "fights to be first" like in Italy, be it parking the car or getting on a bus) and somatic traits.

As homo academicus working in an international institution, I was immersed in an academic culture analogous to those I had already experienced in Italy or the USA. I can, of course, point out several significant cultural differences between an Italian, an American and a Finnish university. Still, the similarities are profound: credits are credits, syllabi are syllabi, and "publish or perish" is the golden rule. And, again, I was working in English. Being that the academy is my everyday paramount experience (Schutz 1945), I am not sure that I have crossed many boundaries either in cultural or social terms. For instance, did I speak or take coffee or lunch with a colleague from the lower classes? I do not think so. I belong to the middle class with no hyphen. All the colleagues and international students I met either belonged to the middle or, in my perception, to the upper-middle and upper class - the same as in Italy and the USA. Within the limits of my 
sociological perception, students and professors coming from the lower class are a rarity.

The existential condition of being in-between, the transition or liminal phase, makes sense only if we still have the idea of boundaries to be transcended. A boundary subsists only if we think it exists; we cannot overcome a boundary we believe is an illusion (Birindelli 2014: 141). Conversely, we cannot overcome a "boundary illusion", no matter how hard we believe in ourselves as cosmopolitan boundary crossers. The point at stake is to decide whether living abroad as an academic (or any higher social status mobility) has become hybrid and blurred, in which case the attempt to scientifically draw boundaries, passages and confines is pointless, whereas tracing the two statuses between ego and alter with a scientific pencil still makes sense. I believe more research into the permeability of social boundaries, the consequent creolization processes, and the creation of liminal social and cultural spaces is called for in order to explore "the 
conditions under which boundaries generate differentiation or dissolve to produce hybridity or new forms of categorization [...] across class, race/ethnic and gender/sexual lines" (Lamont and Molnár 2002: 187).

As a cultural sociologist, I am not sure I have crossed distinct social and cultural boundaries. I would say that my cosmopolitanism can be defined as a middle-class occupational and experiential culture that implies an appreciation of varied lifestyles (Hannerz 1990). At the end of this contribution I will try to persuade the reader that concentrating the analytical focus on middle-class cultural experiences does not constitute a scientific limit within cosmopolitan studies, and that even my thin cross-cultural experience is significant in constituting a potential openness toward otherness. 


\section{The European Double Boundary}

Simmel's concept of "double boundary" can be used heuristically to grasp both individual and collective identities, formations and transformations. Thus, we can speculate about a "double Other" (intra- and extra- European) diachronic recognition process. European heritage can be defined by reference to an external other; the other side of the coin is represented by the internal other. Following the double boundary dialectics, Europeans are boundaries: Italian/non-Italians, Europeans/non- Europeans and so on. Simmel does not believe in a synthetic formula that would make the people of the "old continent" feel comfortable with themselves - as "Europeans" or "Cosmopolitans". The "once and for all" solution pertains more to a religious, ideological sphere, rather than to a scientific paradigm or a political process.

In this sense the cosmopolitan synthesis (or meta-synthesis) can be grasped easily as a belief, or as a normative dimension. Even 
in this case we face analytical difficulties in thinking of "Europeanism" as a belief, because we lack a shared foundation myth.

What is the "European Dream"? The first time I ever encountered the expression was in the title of a book by Rifkin (2004). The American scholar sees the Europeanization process as a unique historical experiment, where (at the time of publication) 25 nations, representing 455 million people, had joined to create a "United States of Europe". Although still in its adolescence, the European Dream is considered by Rifkin to be the first transnational vision, one far better suited to the next stage in the human journey, meaning a radically globalized world. He believes Europeans are beginning to adopt a new global consciousness that extends beyond the borders of their nation-states and that Europeans' mindfulness is embedded in an increasingly interconnected world. While the American Dream is deeply personal and little concerned with the rest of humanity, 
the European Dream is considered more expansive and systemic, and therefore more bound to the welfare of the planet.

Rifkin enucleates several antinomic characteristics of the two dreams. The American Dream emphasizes economic growth, personal wealth and independence; the new European Dream focuses more on sustainable development, quality of life and interdependence. The American Dream depends on assimilation, while the European Dream is based on preserving one's cultural identity and living in a multicultural world. The American Dream is wedded to love of country and patriotism; the European Dream is more cosmopolitan and less territorial.

I see several problems with Rifkin's approach. For instance, the economic crisis and massive immigration in Europe brought ethnic intolerance and political and cultural divisions back to the center of the debate. Rifkin is also occasionally inaccurate; he writes: "Workers often start their weekends on Thursday and don't go back to work until Tuesday." (2004: 50). This is an odd 
statement, and gives the European reader a lot to think about, especially accompanied by the opinion that the American Dream pays homage to the work ethic, while the European Dream is more attuned to leisure and "deep play".

For us [Americans], idleness still conjures up a lax morality. Europeans, on the other hand, covet idleness. They take the time to smell the roses. To really enjoy life, my European friends say to me, one must be willing to surrender to the moment and wait to see what might come one's way. (Rifkin 2004: 117)

Rifkin's viewpoint seems to be of an American scholar on vacation in the old continent. He is an example of the (academic) class consciousness of frequent travelers (Calhoun 2003).

Another major problem with Rifkin's approach comes with the European people in the flesh. I am European and I had never heard the expression "European Dream". Myths are cultural clichés, stories whose patterns we recognize instantly. To be 
considered a foundation myth, the "European Dream" would need to be a clear and simple idea that is felt and shared by the people. The recognition and awareness of the European dream cannot be the result of a historical-philosophical deconstruction and reconstruction. In short, if you need to be a doctor of philosophy in order to share an idea of who we are as Europeans, we cannot consider this a foundation myth from the sociological and anthropological perspective.

A myth is a story drawn from society's history. The story has been told and retold over time, becoming a source of interpretive metaphors. It is increasingly standardized, conventionalized and abstracted until it has finally been reduced to a deeply encoded and resonant set of symbols, icons, clichés or stereotypes (Slotkin 1986). A myth expresses a society's ideology in the form of a symbolic narrative, rather than in a discursive or argumentative form: metaphorical and suggestive rather than logical and analytical. For an American, allusions to "the 
Frontier" evoke the implicit understanding of the entire historical scenario (Slotkin 1986). Is this the case of the “European Dream”?

The mythologization of history is common to all cultures, and it is of critical importance to the development and maintenance of the modern nation-state (Smith 1999) - as in Anderson's "imagined communities" (1983). People are born into the organic communities of family, clan and tribe; they have to be taught to imagine themselves as Europeans or cosmopolitans through organized public rituals, provided in school or by the mass media (Slotkin 2000). Exposure to global media and social networks is not enough.

Is it possible to imagine a transnational European mythologization? European institutions have helped people to imagine themselves as Europeans by organizing, for instance, the "Festival of Europe". Through rituals, people may start to share basic values and beliefs that create an ideological 
consensus. The base of the European Dream is to believe in a shared history: heirs of a common past responsible for a common future. Essentially, a foundation myth consists of a narrative linking the past, present and future of a people. If we consider World War II as a narrative turning point (a before and a clearly different after), we can grasp the beginnings of the modern European narrative. Delanty (2009) considers the European heritage also as trauma, and the Europeanization process as an attempt to avoid our common conflictual past. However, the European narrative is unclear for the present and the future. If we adopt Saint Augustine's conception of time and narrative present of the past, present of the present, present of the future we realize that the lack or fragility of one of the three times does not allow us to create a virtuous narrative circle. According to Bauman (1998), the European Dream sometimes resembles a ghost, a specter, which is something quite different from a “dream". 


\section{The Cosmopolitan Stranger}

Still drawing upon Simmel, it is hard to think about cosmopolitanism through the double boundary dialectic, precisely because cosmopolitanism is a meta-synthesis capable of transcending any cultural boundary. Beck imagines a "bridge" constructed through active tolerance of the cultural other, capable of bringing a shift from an "either-or logic" to a "bothand logic" in the collective conscience (Beck 2006). The cosmopolitan spirit seems to be the bridge across all global cultural boundaries. Therefore, cosmopolitanism appears more like a new "no-boundary"; an attempt to go beyond not only the nation-state but also to overcome postmodernism, relativism and multiculturalism, by finding a new grand narrative for the global Self/Other recognition process. If we were to adopt Simmel's double boundary approach, we would need to meet "aliens", 
non-humans, to contemplate cosmopolitanism through the double boundary dialectic.

The cosmopolitan subject represented in some social science literature is a person who can think and live a "final transcendence" and liberate himself once and for all from all boundaries. Following Simmel, a person who finds such a "Zenith", a sort of "in-between in itself", is an individual who risks falling in a "no-where": a phantasmagoric representation of our globalized world. In more traditional terms, it is a fideistic narrative. However, it is a belief without a clear and shared plot. It is an undefined story without exemplary characters, so it is up to the cosmopolitan individual to find heroes and villains along the way to construct his or her idea of who is a good citizen of the world. From another sociological viewpoint, we could ask ourselves from which ubi consistam do the cosmopolitans realize such a cosmological coniunctio oppositorum? Simmel's insights on the figure of the Stranger (1908/1971) might shed 
sociological light on the situated socio-cultural place of a cosmopolitan type of person. Simmel's Stranger, unlike a wanderer, does not merely come today and go tomorrow; he "comes today and stays tomorrow", bringing qualities into the group that "do not and cannot stem from the group itself." While "he has not belonged to [the group] from the beginning", he nevertheless "has not moved on, has not quite overcome the freedom of coming and going" (Simmel 1908/1950: 402).

Simmel's Stranger is not a marginalized person as in Schütz's conceptualization (1944). In Simmel's view, the Stranger has certain key characteristics: he is a trader, is not an "owner of soil" and has a "bird's eye view". The stranger belongs to an élite of talented subjects who have something precious to offer to the locals: an external, objective point of view (Coser 1972). Is this also the case for the cosmopolitan (intellectual) profile we are trying to sketch here? Does the cosmopolitan stranger teach the local how to become a citizen of the world? 
According to Simmel, as a group member the Stranger is near and far at the same time. The knowledgeable cosmopolitan in a certain sense is far and far at the same time in relation to the different life worlds of the locals; is near and near at the same time in relation to his/her class belonging.

Apparently, the "Cosmopolitan Self" is not confined within particular (local) identities. Several scholars portray the cosmopolitan as a subject who feels greater commitment to international communities and organizations than to local cultures and communities (the international community of scholars, the human rights community, the artistic community, etc.). "The world citizen is socialized in such a way that (s)he recognizes common humanity before particular sociality in strangers - the human being before the concreteness or immediacy of brotherhood, sisterhood, fellowship or friendship" (Ossewaarde 2007: 376). This broader identification is called “cosmopolitan virtue" (Turner 2002: 47): grounded on 
knowledge about humanity, and moral obligations to humanity (Ossewaarde 2007), in the form of "cultivating humanity" (Nussbaum 1996).

Extraterritorial does not mean extra-social; the cosmopolitan person still belongs to a social group. We are not very far from the extraterritorial Latin-speaking and -writing scholastic elites of medieval Europe, before the formation of the nation-state (Bauman 1998). Szerszynski and Urry (2006), interpreting Latour (2004), encourage us to think about the form of cosmopolitanism in which people are not asked to detach themselves from their particular place, gods and cosmos to conquer cosmopolitan emancipation.

Ossewaarde points out, "Claiming to speak from no place, no social position, and no identity except as 'friend of humanity', world citizenship defines itself as a deliberate attempt to abolish exclusion" (Ossewaarde 2007: 375). In reference to Joseph de Maistre, Ossewaarde states that "human beings endowed with 
nothing more than their humanity are nowhere to be found and to all practical intents unimaginable" (Ossewaarde 2007: 367). He thus agrees with Elias (1991: 163) that "the concept of the human being without social characteristics is too vague to serve as a sociological framework, and is also tainted with a slight odour of enlightenment ideals and rootless individualism" (ibid.: 367).

Critics of (ethical) cosmopolitanism argue that the moral community of humankind posited by universalist cosmopolitan theorists does not reflect the reality of the human condition. Nussbaum underlines that the invitation to world citizenship sounds like an invitation to lose your friends, neighbors and colleagues - "an invitation to be an exile" (Nussbaum 1996: 7).

The solution proposed by Beck is "rooted cosmopolitanism". Unlike the cosmopolitanism associated with mobile elites, Beck argues that "rooted cosmopolitanism" promotes an ethical engagement with otherness. The attempt raises new critiques: 
"Aware of these charges of unrealism and utopian idealism, contemporary discussions of the cosmopolitan subject are couched in realist terms" (Marotta 2010: 120).

\section{The Blasé Cosmopolitan: From Metropolis to Cosmopolis}

Beck (2006) suggests what has become a shared assumption in the cosmopolitan approach: problems raised by globalization (new risks) will generate tension towards a renewed (fraternal) universalism. Such a cosmopolitan response is intended as "the only way out" to face the fears of a globalized world. Adopting a pluralistic theoretical approach, no-one asks us to choose between Hobbes and Locke. We can thus take into account another potential scenario. Global fears might trigger a particularistic and individualistic withdrawal, reinforcing the construction of a "minimal Self" (Lasch 1984): a contracted and defensive self, entirely committed to protecting itself from the adversities of modern daily life. It is a lonely Self-identity 
lacking serious bonds with Otherness, constructed in a society that encourages self-absorption.

The cosmopolitan person seems a bit lonely within this dystopic scenario. He/she must realize humanness with a redefined fundamental human need-value: the need for rootedness (Fromm 1959). Human beings, according to Fromm, are called to pursue new roots, adopting a creative criterion to satisfy their need for relatedness to the world. Therefore, the supertranscendent cosmopolitan person, besides roots, might have problems with two other human value-needs depicted by Fromm: relatedness and sense of identity.

The process of identity construction portrayed in some cosmopolitan literature overturns the order of key life-span passages. We feel related first to a specific "someone", only afterward to the abstract idea of a human being: "love thy neighbor" comes after the encounter with $a$ neighbor. While reading cosmopolitan literature, sometimes self-identity seems 
to anticipate identification; this is probably due to the rarity of cosmopolitan sociological reflection linked with social psychology. The most prominent disciplinary connection is with political philosophy, a discipline that concentrates its analysis mainly on the "citizen", an already grown-up subject with little to say about his/her socialization through childhood and adolescence.

It is difficult to imagine a cosmopolitan sense of identity that aims at the elimination of the accident of birth (Seneca, De Otio 1987). Would locals, without the socialization and knowledge of acquaintance first, define themselves as cosmopolitan or would they become victims of anomie and alienation in a "society of strangers" (Ossewaarde 2007)? The citizen of the globalized world might be exposed to feelings of meaninglessness, loneliness, mistrust, insecurity and anxiety (Bauman 2003; Giddens 1991). 
Going back to Simmel might help us to interpret the link between people's identity and the culturally globalized world in a different vein. Simmel depicted the metropolis as a site of a cultural crisis: "the atrophy of individual culture through the hypertrophy of objective culture" (1918/1971: 338). It is the failed mediation attempted in modernity between the objective culture of things and the subjective culture of personal development (Weinstein and Weinstein 1989).

The metropolitan man of the time was considered the boundary between two boundaries: pure organic solidarity versus the pure gesellschaft of isolated individuals. The metropolis was the place of conflict and attempts at unification between the identification of the individual with a "general human quality" and the individual's expression of uniqueness and difference from others - which echoes the contemporary cosmopolitan approach toward the sense of personal identity in a globalized world. According to Simmel (1902/1964), the 
mental life of the metropolis at the beginning of the last century degenerated into a series of defense mechanisms; the double boundary became a wall behind which an over-inflated self without cultural resources, or without the capacity to mediate between subjective and objective culture, hid itself. Within the social and cultural forms of the metropolis, the "blasé personality", confused by the ephemerality and instability of modern conditions, becomes unresponsive to suffering and injustice and withdraws into a cocoon of uniquely subjective considerations. According to Simmel, the blasé/neurasthenic personality is characterized by ceaseless anxiety and nervousness, which prevents the metropolitan person from fully committing to transcendent goals. Moreover, the "blasé" is a new type of individual who is not defined by class, gender or professional or ethnic identity but instead by a psychological disposition. The "blasé" is a prototype of a negative or indifferent reaction towards both new and old risks of a 
globalized world: instead of embracing otherness, he/she retreats from the common destiny

of humanity and constructs a defensive self-identity.

We can think of the blasé attitude as a mask worn by the social actor who tries to display the feeling of being "at home in the world". We either re-define the meaning of "feeling at home", or we can say that the ego by definition cannot feel at home everywhere. One necessarily feels more comfortable in some places and less in others. Therefore, either flaunting the ability to be at ease anywhere requires a mask, or what is passed off as the worldly everywhere is instead a distinctive somewhere, with specific social and cultural characteristics.

Interpreting Simmel's “adventurer” social type (1910/1959), we can imagine the "cosmopolitan adventurer" as a person affected by "presentification syndrome". The most general form of adventure is "dropping out of the continuity of life". The more "adventurous an adventure", that is, the more fully it realizes its 
idea, the more dreamlike it becomes in our memory. The experience of an adventure is independent from the timely "before and after"; its boundaries are defined regardless of time. We speak of adventure precisely when continuity with life is disregarded on principle. Thus, the adventurer is an ahistorical individual, a person who lives in the present. Simmel's Casanova was in fact "entirely dominated by the feeling of the present"; it was impossible for him to enter into a future relationship precisely because his temperament was fully oriented to the present.

We could thus imagine a global adventurer prone to an "aestheticization of the Other", and thus conceptualize a sort of "Cosmopolitan Simulacrum": an image without resemblance (Deleuze 1990); the copy of a copy, with no relation to reality whatsoever - the "hyperreal" (Baudrillard 1994). Alternatively, we can concentrate simply on the Latin meaning of "simulacrum": "figure”, "statue", "idol” or "specter". The Latin 
meaning leads us again to think whether cosmopolitan experiences abroad truly foster cultural openness through actual occasions to meet the Other in the flesh, or instead support a more aesthetic "touristic gaze" (Urry and Larsen 2011).

A critical interpretation of the intellectual, aesthetic and romantic representation of "Europe without Europeans", a sort of "European Simulacrum", suggests that traveling to or within the Old World does not necessarily mean crossing social and cultural boundaries. Thus, the cosmopolitan globetrotter in Europe might not be the best "broker of knowledge" in our globalized world. In Simmel's words:

I am convinced there will come a time when Europe will be to America as Athens to the later Romans: a travel destination for the young in search of culture, a place full of interesting ruins and great memories, $a$ source of supplies for artists, scholars and chattering intellectuals. (Simmel 1918, cited in Harrington 2005: 68, emphasis added) 


\section{From Cosmopolitan Simulacrum to Modest Middle Class}

\section{Cosmopolitan Canopy}

In this contribution I have tried to avoid taking sides in the contraposition between empirically oriented sociologists - who study forms of "lived cosmopolitanism" - and authors working on cosmopolitanism in philosophical and normative veins. David Inglis (2014) has challenged what he considers an unproductive division between the empirical and normative domains. Here I would like to clarify the apparently "uncosmopolitan outcome" of a sociologist trying to adopt a cosmopolitan studies approach - as Inglis points out, "a very ironic state of affairs" (2014: 100).

Although my sociological and anthropological approach aims at interpreting "really existing" forms of cosmopolitan orientations and practices among concrete individuals and groups (Robbins 1992), I would like to challenge the classic critique of a cosmopolitan expression of white, western, upper- 
class privilege (Calhoun 2003; Ossewaarde 2007; Skrbis and Woodward 2007).

Firstly, the traveling bourgeoisie constitutes a frame of reference for how people belonging to other social classes may envision a "good life" in a globalized world (Jansson 2016). Secondly, with the spread of mass tourism and the majority of migrants being middle class, we realize the magnitude of this social group, which goes beyond the upper class and embraces the upper-middle and middle class. Thirdly, the bourgeoisie has been the protagonist and engine of modernity and late modernity: this continues to be the case for the cosmopolitan experience. If these considerations ring true, my argument, reduced to the bone, is that studying the global mobility of the upper-middle and middle class is a crucial sociological endeavor.

As a final consideration, I would like to highlight the importance of low-intensity aesthetic and cultural forms of 
cosmopolitanism. As Cicchelli puts it (2012), an experience abroad might foster an education to alterity, a sort of cosmopolitan socialization or Bildung. He questions whether this praxis is oriented more towards aesthetic, cultural, ethical or political forms of cosmopolitanism. Adopting this clarifying grid, we may affirm that several scholars construct a hierarchical scale where aesthetic orientations constitute the lower and most superficial step for the development of cosmopolitan spirit, and the political orientation represents the highest. This hierarchy within cosmopolitanism's dimensions (Gemann Molz 2011) opposes an authentic form of cosmopolitan openness to another that is more superficial (Cicchelli et al. 2016). Basically, the awareness of different cultures channeled by aesthetic and cultural cosmopolitanism is often considered "superficial and cosmetic" (Sassatelli 2012: 235).

Simmel's metropolitan man failed to find a mediation between objective and subjective culture, that is, to find a 
meaningful self-narrative where one could glimpse the other that is in us and think of "oneself as another" (Ricoeur 1992). Hannerz, in his seminal work, admitted that cosmopolitanism often has a narcissistic streak (1990: 240). Several years later, the Swedish anthropologist pointed out the two faces of cosmopolitanism: one more cultural and one more political. The latter, he argued, is "often a cosmopolitanism with a worried face, trying to come to grips with very large problems", whereas in its cultural dimension it may be a cosmopolitanism happily "enjoying new sights, sounds and tastes, new people": "And in combination, and merging with one another, they may be that thick form of cosmopolitanism, where experience and symbolism can motivate identification and a will to action" (Hannerz 2005: 204).

Hannerz's invitation is to pay attention to "on the ground" cosmopolitanism, where people engage in everyday cultural activities (Cicchelli and Octobre 2015). In some liminal public 
spaces the cosmopolitan "simulacrum" can become a "canopy". These are everyday life stages that allow people from different backgrounds "to slow down and indulge themselves, observing, pondering, and in effect, doing their own folk ethnography, testing or substantiating stereotypes and prejudices or, rarely, acknowledging something fundamentally new about the other" (Anderson 2004: 25). These spaces, at home or abroad, can foster "a kind of confidence, and a code of civility":

...expanding out of the neighborhood to take in more of the world, is not to be underestimated. A kind of modest bottom-up cosmopolitics may at least be a matter of maintaining a certain immunity to extreme antagonisms, of hatred or of fear. (Hannerz 2005: 212, emphasis added)

Hannerz notes that in the decades after the fall of the Berlin Wall there has been a renewed interest in cosmopolitanism among social scientists, while headlines and storylines portray new wars, human wrongs, things falling apart. "Yet those may again 
be the kinds of things that go most readily precisely into headlines and storylines. It may be worth looking more closely for the small signs of banal, or quotidian, or vernacular, or lowintensity cosmopolitanism" (Hannerz 2005: 27). 


\section{References}

Anderson, B. (1983). Imagined communities: Reflections on the origin and spread of nationalism. London: Verso.

Anderson, E. (2004). The cosmopolitan canopy. The Annals of the American Academy of Political and Social Science, 595(1), 1431.

Arditi, J. (1994). Geertz, Kuhn and the idea of a cultural paradigm. British Journal of Sociology, 597-617.

Baudrillard, J. (1994). Simulacra and simulation. Ann Arbor: University of Michigan Press.

Bauman, Z. (1998). Europe of strangers. Working Paper No. 3, ESRC Transnational Communities Programme, pp. 1-17.

Bauman, Z. (2003). Liquid love: On the frailty of human bonds. Cambridge: Polity Press.

Beck, U. (2006). The cosmopolitan vision. Cambridge: Polity. Beck, U., \& Grande, E. (2007). Cosmopolitan Europe. Cambridge: Polity. 
Birindelli, P. (2014). The passage from youth to adulthood: Narrative and cultural thresholds. Lenham: University Press of America (Rowman \& Littlefield).

Birindelli, P. (2017). The cultural experience of international students: Narratives from North and South Europe. Retrieved from http://culturalexperienceabroad.blogspot.com/.

Calhoun, C. (2003). The class consciousness of frequent travellers: Towards a critique of actually existing cosmopolitanism. In D. Archibugi (Ed.), Debating cosmopolitics (pp. 86-116). London: Verso.

Cicchelli, V. (2012). L'esprit cosmopolite: Voyages de formation des jeunes en Europe. Paris: Presses de Sciences Po.

Cicchelli, V., Octobre, S. (2015) Sur le Cosmopolitisme Esthetique des Jeunes. Le Débat 183: 101-10109.

Cicchelli, V., Octobre, S., \& Riegel, V. (2016). After the omnivore, the cosmopolitan amateur: Reflections about aesthetic cosmopolitanism. Global Studies Journal, 9(1), 55-69. 
Coser, L.A. (1972) The alien as a servant of power: Court Jews and Christian renegades. American Sociological Review (37): 574581.

Delanty, G. (2009). The European heritage: History, memory, and time. In C. Rumford (Ed.), The Sage handbook of European studies (pp. 36-51). London: Sage.

Delueze, G. (1990). The logic of sense. New York: Columbia University Press. Elias, N. (1991). The society of individuals. Oxford: Basil Blackwell.

Frank, A. (1987). Review essay. Symbolic Interaction, 10(2), 295311.

Fromm, E. (1959). Values, psychology and human existence. In A. H. Maslow (Ed.), New knowledge in human values. New York: Harper \& Row.

Gemann Molz, J. (2011). Cosmopolitanism and consumption. In M. Rovisco \& M. Nowicka (Eds.), The Ashgate research companion to cosmopolitanism (pp. 33-52). Farnham: Ashgate. 
Giddens, A. (1991). Modernity and self-identity: Self and society in the late modern age. Stanford: Stanford University Press.

Hannerz, U. (1990). Cosmopolitans and locals in world culture. In M. Featherstone (Ed.), Global culture: Nationalism, globalization and modernity. London: Sage.

Hannerz, U. (2005). Two faces of cosmopolitanism: Culture and politics. Statsvetenskaplig tidskrift, 107(3), 199-213.

Harrington, A. (2005). Introduction to Georg Simmel's essay 'Europe and America in world history. European Journal of Social Theory, 8(1), 63-72.

Inglis, D. (2014). Cosmopolitans and cosmopolitanism: Between and beyond sociology and political philosophy. Journal of Sociology, 50(2), 99-114.

Jansson, A. (2016). Mobile elites: Understanding the ambiguous lifeworlds of sojourners, dwellers and homecomers. European Journal of Cultural Studies, 19(5), 421-434. 
Lamont, M., \& Aksartova, S. (2002). Ordinary cosmopolitanisms strategies for bridging racial boundaries among working-class men. Theory Culture \& Society, 19(4), 1-25.

Lamont, M., \& Molnár, V. (2002). The study of boundaries in the social sciences. Annual Review of Sociology, 28, 167-195.

Lasch, C. (1984). The minimal self: Psychic survival in troubled times. New York: Norton.

Latour, B. (2004). Whose cosmos, which cosmopolitics? Comments on the peace terms of Ulrich Beck. Common Knowledge, 10(3), 450-462.

Leed, E. J. (1991). The mind of the traveler: From Gilgamesh to global tourism. New York: Basic.

Levine, D. N. (1989). Simmel as a resource for sociological metatheory. Sociological Theory, 7(2), 161-174.

Marotta, V. P. (2010). The cosmopolitan stranger. In S. Van Hooft \& W. Vandekerckhove (Eds.), Questioning cosmopolitanism (pp. 105-120). Netherlands: Springer. 
Nussbaum, M. C. (1996). For love of country: Debating the limits of patriotism. Boston: Beacon Press.

Ossewaarde, M. (2007). Cosmopolitanism and the society of strangers. Current Sociology, 55(3), 367-388.

Rifkin, J. (2004). The European dream: How Europe's vision of the future is quietly eclipsing the American dream. Cambridge: Polity.

Robbins, B. (1992). Comparative cosmopolitanism. Social Text, 31(2), 169-186.

Sassatelli, M. (2012). Festivals, museums, exhibitions. Aesthetic cosmopolitanism in the cultural public sphere. In G. Delanty (Ed.), Routledge handbook of cosmopolitan studies (pp. 232244). London: Routledge.

Schütz, A. (1944). The stranger: An essay in social psychology. American Journal of Sociology, 49(6), 499-507. 
Schutz, A. (1945). On multiple realities. In A. Schutz (Ed.), Collected papers I: The problem of social reality. The Hague: Martinus Nijhoff.

Seneca. (1987). De Otio (A. Padgen, Ed.). Cambridge: Cambridge University Press. Simmel, G. (1902/1964). The metropolis and mental life. In K. H. Wolff (Ed.), Sociology of Georg Simmel (pp. 409-424). New York: Free Press.

Simmel, G. (1907/1986). Schopenhauer and Nietzsche. Amherst: Univ. of Massachusetts Press.

Simmel, G. (1908/1950). The stranger. In K. Wolff (Ed.), The sociology of Georg Simmel (pp. 402-408). New York: Free Press.

Simmel, G. (1908/1971). The stranger. In D. N. Levine (Ed.), George Simmel: On individuality and social forms (pp. 143149). Chicago: University of Chicago Press. 
Simmel, G. (1910/1959). In K. H. Wolff (Ed.), Georg Simmel, 1858-1918: A collection of essays, with translations and a bibliography. Columbus: Ohio State University Press.

Simmel, G. (1918/1971). The transcendent character of life. In D.

N. Levine (Ed.), Georg Simmel: On individuality and social forms (pp. 353-374). Chicago: University of Chicago Press.

Skrbis, Z., Woodward I. (2007) The ambivalence of ordinary cosmopolitanism: Investigating the limits of cosmopolitan openness. Sociological Review 55(4): 730-7747.

Slotkin, R. (1986). Myth and the production of history. In S. Bercovitch \& J. Myry (Eds.), Ideology and classic American literature (pp. 70-90). Cambridge: Cambridge University Press.

Slotkin, R. (2000). Regeneration through violence: The mythology of the American frontier, 1600-1860. Norman: University of Oklahoma Press.

Smith, A. D. (1999). Myths and memories of the nation. Oxford: Oxford University Press. 
Szerszynski, B., \& Urry, J. (2006). Visuality, mobility and the cosmopolitan: Inhabiting the world from afar. The British Journal of Sociology, 57(1), 113-131.

Turner, B. S. (2002). Cosmopolitan virtue, globalization and patriotism. Theory, Culture \& Society, 19(1-2), 45-63.

Urry, J., \& Larsen, J. (2011). The tourist gaze 3.0. London: Sage.

Weinstein, D., \& Weinstein, M. A. (1989). Simmel and the dialectic of the double boundary. Sociological Inquiry, 59(1), $48-59$. 